\title{
Order in the House: Epilogue
}

\author{
Maaike van Berkel \\ Professor of Medieval History, Department of History, Art History and \\ Classics, Radboud University Nijmegen, Nijmegen, The Netherlands \\ m.vanberkel@let.ru.nl
}

\begin{abstract}
The contributions to this Special Issue of the Journal of Abbasid Studies show that the later third/ninth to the early fifth/eleventh century witnessed the output of a variety of voluminous books, not only in the Arabic-Islamic tradition, but in chronologically parallel cultures as well. For an overall understanding of the writerly culture of the era, further exploration of the organisation of information and the development of tools to locate data is called for. My epilogue offers a step in this direction against the backdrop of fourth/tenth-century caliphal administration and the organisation of archives on the one hand, and a comparison with the later and much more studied Mamluk writerly culture on the other.
\end{abstract}

\section{Keywords}

Abbasid intellectual history - encyclopaedism - Mamluk intellectual history organization of knowledge

\section{Introduction}

From al-Āmidī to al-Majūsī, in Cordoba and Baghdad, from an erotic compendium to a biographical dictionary, this collection of articles has convincingly demonstrated that the period from the later third/ninth to the early fifth/eleventh century witnessed an impressive output of Arabic "big books" in various genres and styles. ${ }^{1}$ It was not only an age of voluminous texts, it was also an age of the spread of large numbers of texts, an era in which a "writerly culture,"

1 The term "big books" is from Julia Bray's contribution to this Special Issue. 
as Shawkat Toorawa coined it in his illuminating monograph on the Baghdadi bookseller Ibn Abī Ṭāhir Ṭayfūr, reached a level of maturity. ${ }^{2}$

Should we label this period an age of encyclopaedism? The authors and editors of this Special Issue are not completely convinced that encyclopaedism is a helpful category to study the voluminous well-organised books of the era. In their introduction Letizia Osti and James Weaver argue convincingly that using the concept of encyclopaedism from the outset is distracting. If we want to fully understand a series of developments shaping the Arabic writerly culture of this period - including new practices of reading and teaching and the (diverse) social contexts in which these books were produced - we need to look beyond preconceived ideas on encyclopaedias. The authors, but especially Julia Bray and Antonella Ghersetti, further warn against a too narrow interpretation of structure and organisation as primarily meant to make these books accessible and ready for consultation. They emphasise that also other aims motivated authors to present and organise information in a certain way such as the quest for a coherent narrative, a consistent vision of the world, or a political agenda and ideology.

The Arabic texts discussed in this Special Issue cover a wide range of topics, styles and disciplines. Furthermore, the comparison with voluminous books from two non-Arabic, but chronologically parallel traditions - the Sanskrit scriptural digests in the Dharmaśāstra and Śaiva Siddhānta traditions from India and the Byzantine Excerpta Historica Constantiniana - illustrates both the broader universal omnipresence of encyclopaedic endeavours and the diversity in styles and traditions. Yet what all of the texts discussed have in common is their (comparatively) voluminous size and their concern for organizing their contents in a structured way with the aim of directing its readers through it. The articles in this Special Issue have given us ample ideas on how these endeavours for organisation resulted in certain practices — such as chronological, geographical, thematic sorting principles - and the use of specific tools - such as chapter headings, tables of contents and crossreferences. What these organisational principles might have meant for reading and teaching practices and how they are embedded in the milieus in which they circulated are questions which are certainly touched upon in the separate articles, but might need further exploration for an overall understanding of the writerly culture of the era.

Such a broader historical embedding of the organisational practices studied in this Special Issue, calls for yet another meeting with the network of inspiring colleagues who were brought together first in Zürich and then in Milan

2 Toorawa, Ibn Abī Ṭāhir Țayfür, 1. 
by Letizia Osti and James Weaver. Looking forward to such a meeting, I will here add an element to this broader embedding based on my own previous research. The era's focus on the organisation of information and the development of tools to locate this information are not restricted to the manuscript and literary tradition. Similar practices are visible in the everyday administration of the caliphate and its successor states and the ideas on organizing (large amounts of) information can therefore be extended to and studied for these more practical arenas of knowledge transfer. While literary texts were "putting the House of Wisdom in order,"3 order had to be kept in the house itself as well. In this epilogue I want to explore how the organisation of the archives and the administrative manuals might be connected to developments in the organisation of information as studied in the literary culture. This is particularly relevant since scribes, kuttāb, were also very prominent among the authors of "big books" and thus partly representative for the milieu in which these texts were produced and read. Finally, I will examine whether there is ground for comparison with the better studied "Mamluk encyclopaedism" in which kuttāb were equally preeminent. Obviously, Mamluk studies is not the only relevant field for comparison, and the collection of articles in this Special Issue demonstrate the relevance of comparison outside the field of Arabic literature. However, the encyclopaedic endeavours under the Mamluks belong to the best studied encyclopaedic traditions in Arabic literature, and by comparing the outcomes of that scholarship to our conclusions we might raise new questions, creating a deeper understanding of the production of "big books" in the period under investigation.

\section{Organizing the Administration}

The scribes of the government administrations of the fourth/tenth century assumed important positions in the writerly culture of their age. They were not only the authors of a substantial number of "big books" produced in the era, but also advertised a "writerly identity" in their professional life. As writers of official documents, they considered themselves the main representatives of a culture that valued the power of the pen. Both as part of their daily tasks at one of the administrative offices and as writers of literary works they were

3 "Putting the House of Wisdom in Order" was the title of the first workshop on this topic in Zürich in February 2016 and is also the title of the collection of articles published as proceedings of this workshop: Weaver, Osti, and Rudolph, Putting the House of Wisdom in Order. 
constantly engaged in the selection, sorting, presentation and retrieval of information.

In the course of the third/ninth century the Abbasid administration had expanded, and scribes of diverse ethnic and religious background were enrolled in the various offices. ${ }^{4}$ Some came from so-called secretarial families who already had relatives working in the state administration. Others were newcomers who built their careers on expertise and support by patrons. These scribes constructed a self-conscious identity, of which being writers and $u d a b \vec{a}^{\prime}$ - cultivated men, generalists, educated in a broad range of disciplines - were the essential characteristics. Obviously, this was an idealised self-image and we may assume that not all scribes were able to live up to the expectations of this standard. However, among them were indeed quite a number of writers, readers and patrons of literary books on diverse fields of knowledge, and as such they played this important role in the literary culture of their age. ${ }^{5}$

The technical specialised knowledge and the general cultural baggage $k u t t a \bar{b}$ were expected to master were laid down in, often, voluminous texts which flourished during the late third/ninth and fourth/tenth century. These so-called adab al-kātib manuals contained the kind of information which was most probably not meant to be consumed from cover to cover at one sitting. How many people would enjoy reading consecutively pages and pages of different forms and styles of various types of letters? Qudama b. Ja'far's Kitāb al-Kharāj is a good example of such a "big" administrative manual. Qudama b. Jafar (d. 337/948) was a scribe working in the Abbasid bureaucracy in the early fourth/tenth century under caliph al-Muqtadir.

If the text was not meant to be read at one sitting, then how did Qudāma facilitate access for his readers? What were the criteria for ordering his material and what kind of tools did he apply to enable the location and retrieval of that material? Qudāma divided his work into eight main sections (manzilāt) of which the first four have been lost. Each manzila is subdivided into a varying number of chapters $(a b w \bar{a} b)$. Both the sections and the chapters are numbered. Since we rely on a unique seventh/thirteenth-century manuscript of the Köprülü Library in Istanbul, ${ }^{6}$ it is difficult to analyse the ways in which the book's structure was visible in the layout of the manuscript(s) of Qudāma's

4 Van Berkel et al., Crisis and Continuity, 93-99.

5 In Ibn al-Nadīm's Fihrist (I, 364) we find many references to books written by scribes; see also his list containing "the names of poets who were scribes" (Ibn al-Nadìm, Fihrist, I, 531-538). For the role of kuttāb in the translation movement, see Gutas, Greek Thought, 128-133.

6 Köprülü Library Ms. 1076, published in facsimile edition by Fuat Sezgin, Frankfurt am Main: Publications of the Institute for the History of Arabic Islamic Sciences 1986. 
own time. Yet in the Köprülü manuscript the titles of the various chapters $(a b w \bar{a} b)$ are distinguished from the body of the text with clear signposts such as spacing, variation in size of letters and the use of bold text.

In his study on the construction of knowledge in Qudāma's text, Paul Heck qualifies the book as "an encyclopaedia, an attempt to define and order particular branches of knowledge in the service of an Islam which was no longer the Islam of tribes, nor solely the Islam of religious specialists, but the Islam of Empire."7 The book is structured according to these various branches of knowledge. The contents of the first four lost sections can be reconstructed on the basis of references made by later authors as well as cross-references in the text itself. The first section is the introduction, the second discusses orthography and tools of writing, the third rhetoric. The fourth section deals with the two most important administrative offices, the office of the land-tax (diwwan $a l-k h a r a \bar{j})$ and that of the state land-holding (dīwān al-diy $\bar{a})$. The fifth section describes the tasks of all other administrative units of the central administration. Section six deals with geography and section seven with jurisprudence. Eight, finally, is concerned with political thought and the art of governance. Within each section we find other clear and logical arrangements of the material. Section five, for example, is divided according to eleven main administrative offices of the central administration in Baghdad. ${ }^{8}$

Another tool for readers to locate information in a voluminous text is a system of cross-references. Qudāma inserts cross-references in his text in two ways: He uses either very short and imprecise descriptions - "according to what has already been described and explained"9 — or he refers to specific sections or chapters of the texts - "We already mentioned this in the third section (manzila)."10 Finally — and again we will have to rely on the seventh/ thirteenth-century manuscript of this text - either the author or (and we cannot be sure about this) some later copyists added tables of contents at the beginning of, at least, section 5-8, summarizing the numbered chapters of each section with the appropriate titles. Admittedly, these tables of contents do not contain references to folio or page, which certainly would have helped to locate specific sections quickly in the body of the text. However, with the clearly defined structure of the text, partly visible in the layout of the page, it would not have taken a reader too long to retrieve the material on a particular topic.

$7 \quad$ Heck, Construction of Knowledge, 1.

8 For a much more detailed analysis of the thematic organisation of the text see Heck, Construction of Knowledge.

9 Qudāma b. Ja'far, Kharāj, 17.

$10 \quad$ Ibid., 37 
Qudāma and his fellow kuttāb were not only selecting and ordering information in their administrative texts. Also in everyday practice at their offices in the administration of the caliphate they had to organise the information contained in the large number of documents that went through their hands. And while putting in order the state's administration they were concerned with the retrievability of everything they had generated, received and stored away in archives. The spread of paper, from the second/eighth century onwards not only played a major role in the spread of big books, but also in the enormous increase of the production of state documents at all levels of the administration. ${ }^{11}$

Since the archives themselves as institutions do not survive, we have to rely on the narrative sources to find out how they were organised and keep in mind at the same time that these narrative sources are prescriptive, laying down guidelines for a smoothly organised archive and not always providing information on the perhaps deviant actual situation. Since I have written elsewhere in more detail about the reconstruction of the archives, ${ }^{12}$ I will restrict myself here to a few general observations on the ordering principles kuttāb seem to have applied in archiving documents. These principles demonstrate a comparable concern for order and retrievability as found in the voluminous texts studied in this Special Issue. Qudāma b. Jaffar's Kitāb al-Kharāj is again a relevant source of information here. In his chapter on the handling of petitions (dìwān al-mazālim) in section five of his book, Qudāma describes in detail the collecting, selecting, ordering and storing of the petitions, the registration of the names of the petitioners and the collection of the responses to these petitions. Qudāma's main concern here seems to have been the retrievability of information once it is stored in the archives. He argues that if the petitioner is to return, "his entire case should be recorded in one place, so that, if a request is made to bring out the case from the dīwān al-mazälim his entire dossier will be found in proper order and in its entirety in one place, and the chief of the dīwān can bring it out without trouble."13

In their administrative texts kuttāb, as many of the other authors of voluminous texts, were concerned with organizing their information in such a way as to make their texts easily accessible for their readers. However, accessibility was not their only concern. In their presentation of the material they also

\footnotetext{
11 Bloom, Paper Before Print.

12 Van Berkel, Reconstructing Archival Practices.

13 Qudāma b. Ja'far, al-Kharäj, 63; transl. Heck, Construction of Knowledge, 87, with small modifications. See for a longer quotation of this section, Van Berkel, Reconstructing Archival Practices.
} 
portrayed their vision of the world and by doing so claimed their own position in it. Their most important message was that good government is only possible through a well-organised and professional class of experts in writing. Writing in all its facets was their identity card. However, they also advertised an ideal of orderly procedures and a well-structured apparatus. Qudāma even uses the structure of the administration in separate offices as an organizing principle in the fifth section of his Kitāb al-Kharäj. Good rulership was only possible through good writing, but also required that there be order in the house.

\section{Comparing Encyclopaedic Endeavours}

Not only in the period investigated in this volume, but also in seventh/ twelfth- to ninth/fifteenth-century Egypt and Syria under Mamluk rule the kuttāb adopted important positions in the literary culture of their age. Many of the voluminous, well-organised books of the Mamluk era were written by authors who were employed as scribes at all levels of the administrative apparatus, among them Shihāb al-Dīn al-Nuwayrī (d. 733/1333), Ibn Faḍl Allāh al-'Umarī (d. 749/1349), and al-Qalqashandī (d. 821/1418).

Does a comparison between the two eras help us better understand the contexts in which the appreciation for bringing together, selecting and organizing large amounts of information flourished? What can the better studied Mamluk era teach us about, for example, the milieus in which these voluminous texts circulated and the reading practices they stimulated or to which they responded? I will formulate here some preliminary thoughts based on this comparison and in doing so, I will move beyond the debate on whether or not we should refer to these voluminous texts as encyclopaedias - a term which is quite often and with less reservation used by scholars studying these later centuries. ${ }^{14}$ In a similar vein, I will leave behind the debates on the paradigm of decadence, decline and lack of creativity which has traditionally been connected to the rise of encyclopaedism in the Mamluk era. During the last two decades scholars such as Thomas Bauer convincingly refuted this paradigm, ${ }^{15}$ and a pattern of decline is equally not a relevant concept for the earlier period.

However, there are two other debates on Mamluk literary culture I would like to discuss here in more detail. The first is on the expansion of a literate mentality among different social groups. Studies by, among others, Konrad Hirschler and Thomas Bauer have demonstrated how progressively from the

\footnotetext{
14 See, for example, Muhanna, Arabic Encyclopaedism, and the discussion on the use of the concept of encyclopaedism in Osti's and Weaver's contribution to this Special Issue.

15 See, for example, Bauer, Mamluk Literature; idem, In Search of "Post-Classical Literature."
} 
sixth/twelfth-seventh/thirteenth centuries onwards new audiences started to participate in writerly culture. ${ }^{16}$ Among them were traders and craftsmen and eventually also people from lower echelons. These new groups engaged as readers - from scholarly texts and documents to children's books - as aural participants in reading sessions, and eventually also as writers and patrons. This expansion in readerships and the increase in centres of learning also facilitated and stimulated the production of "encyclopaedic works," as Elias Muhanna has argued. ${ }^{17}$ The scholarship on Mamluk readerships can shed new light on the characteristics of the readers and writers of earlier voluminous texts. ${ }^{18}$ Kuttāb were certainly prominent among the writers and readers of these texts and studying their professional and social environment engenders better understanding of the contexts in which the texts were circulated. However, kuttāb were not the only milieu with interest in the collection and organization of large amounts of information. Shawkat Toorawa convincingly showed the expansion of readerships among various social elites, also outside the court circles, in the course of the third/ninth century. ${ }^{19}$ We still need to dig deeper into the features and developments of writerly milieus in the course of the fourth/tenth century.

In exploring milieus of writerly culture, we might also profit from linking up with a second avenue of Mamluk research: the collection, prioritising and ordering of large amounts of written information in fields outside the literary voluminous works. One of these fields is the archive. Endeavours to select and collect information and concerns for accessibility are common to both archival practices and voluminous books, as has already been put forward in this article..$^{20}$ Yet not only the reconstruction of archives, but also a broader understanding of pragmatic literacy - literacy which directly serves functional actions - will enhance our perception of the writerly culture of the era. Elias Muhanna has emphasised the interrelationship between empire and encyclopaedism for the Mamluk era. Comparisons outside the field of Arabic literature have shown similar conclusions. In his seminal study on medieval England, for example, Michael Clanchy emphasised the role of "pragmatic literacy," especially the increasing bureaucracy and its use of written documents,

16 Bauer, Mamluk Literature; Hirschler, Written Word.

17 Muhanna, Arabic Encyclopaedism, 347-351.

18 On diverse readerships and different social groups involved in the use of writing, see also the extensive research on these topics by historians of medieval Europa, in Mostert, Bibliography Medieval Communication (especially chapter 12 on the use of writing by different social groups).

19 Toorawa, Ibn Abī Ṭāhir Țayfür, 123-129.

20 For a thought-provoking reconceptualization of archives, see El-Leithy, Living Documents. 
in the rise of a literate mentality. ${ }^{21}$ In a similar vein, Florinda de Simini argues in her contribution to this Special Issue that the production and use of anthological works such as the Sanskrit scriptural digests might be better understood when studied through the lens of the creation of archives and the spreading of archival practices and how these relate to processes of knowledge preservation in the court or the monastery. Also Dariya Rafiyenko's contribution to this Special Issue, on the Byzantine Excerpta Historica Constantiniana, clearly demonstrates for yet another contemporary literary tradition the close interrelationship between, on the one hand, empire, and, on the other, organising endeavours and the structuring and preserving of knowledge. The production of this reference work was instigated by Emperor Constantine vII himself, and its intended readership consisted of officials and the learned elite of the imperial court. Within the Arabic tradition, we might further profit from recent studies by papyrologists and others working on documentary sources and archival practices. ${ }^{22}$ Finally, studies on book collections and libraries by, for example, Konrad Hirschler on the Mamluk era and Houari Touati for earlier centuries, will also direct us towards a better understanding of the diverse principles of ordering information and the tools developed to locate specific pieces in it. ${ }^{23}$

The rich material on voluminous texts of the period from the later third/ ninth to the early fifth/eleventh century and the organisation of the information they contained, brought together and analysed in two special issues - in Asiatische Studien and this issue of the Journal of Abbasid Studies - has provided a wealth of information on the organizing mind of the era. The scholarship on Mamluk literacy and other encyclopaedic endeavours might inspire us to take a next step and explore in even more detail the contexts and motivations behind these developments.

\section{References}

\section{Primary Sources}

Ibn al-Nadīm, Kitāb al-Fihrist, ed. by A.F. Sayyid, London: Al-Furqan Islamic Heritage Foundation, 2009

Qudāma b. Ja'far, Kitāb al-Kharāj wa-șinā'at al-kitāba, ed. by Muḥammad Ḥusayn al-Zubaydī, Baghdad: Dār al-Rashīd li-l-Nashr, 1981

\footnotetext{
21 Muhanna, Arabic Encyclopaedism, 351; Clanchy, Memory to Written Record.

22 See, for example, Sijpesteijn, Archival Mind.

23 Hirschler, Written Word; Touati, L'Armoire.
} 


\section{Secondary Sources}

Bauer, Thomas, Mamluk Literature: Misunderstandings and New Approaches, in: Mamlūk Studies Review 9/2 (2005), 105-132

Bauer, Thomas, In Search of "Post-Classical Literature": A Review Article, in: Mamlūk Studies Review 11/2 (2007), 137-167

Bloom, Jonathan M., Paper Before Print: The History and Impact of Paper in the Islamic World, New Haven: Yale University Press, 2001

Clanchy, Michael, From Memory to Written Record: England 1066-1307, 2nd revised edition, Oxford: Blackwell Publishing, 1993

Gutas, Dimitri, Greek Though, Arabic Culture: The Graeco-Arabic Translation Movement in Baghdad and Early Abbāsid Society (2nd-4th/8th-10th centuries), London: Routledge, 1998

Heck, Paul, The Construction of Knowledge in Islamic Civilization: Qudāma b. Jaffar and his Kitāb al-Kharāj wa-șinā'at al-kitāaba, Leiden: Brill, 2002

Hirschler, Konrad, The Written Word in the Medieval Arabic Lands: A Social and Cultural History of Reading Practices, Edinburgh: Edinburgh University Press, 2012

El-Leithy, Tamer, Living Documents, Dying Archives: Towards a Historical Anthropology of Medieval Arabic Archives, in: Al-Qantara 32 (2011), 389-434

Mostert, Marco, A Bibliography of Works on Medieval Communication, Turnhout: Brepols, 2012

Muhanna, Elias, Why was the Fourteenth Century a Century of Arabic Encyclopaedism?, in: Jason König and Greg Woolf (eds.), Encyclopaedism from Antiquity to the Renaissance, Cambridge: Cambridge University Press, 2013, 343-356

Sijpesteijn, Petra M., The Archival Mind in Early Islamic Egypt: Two Arabic Papyri, in: Petra M. Sijpesteijn, et al. (eds.), From al-Andalus to Khurasan. Documents from the Medieval Muslim World, Leiden: Brill, 2007, 163-186

Toorawa, Shawkat M., Ibn Abì Țāhir Ṭayfür and Arabic Writerly Culture: A Ninth-Century Bookman in Baghdad, London: Routledge, 2005

Touati, Houari, L'armoire à sagesse: Bibliothèques et collections en Islam, Paris: Aubier, 2003

Van Berkel, Maaike et al., Crisis and Continuity at the Abbasid Court: Formal and Informal Politics in the Caliphate of al-Muqtadir (295-320/908-932), Leiden: Brill, 2013

Van Berkel, Maaike, Reconstructing Archival Practices in Abbasid Baghdad, in:Journal of Abbasid Studies 1/1 (2014), 7-22

Weaver, James, Letizia Osti and Ulrich Rudolph (eds.), Special Issue: Putting the House of Wisdom in Order: The Fourth Islamic Century and the Impulse to Classify, Arrange and Inventory, in: Asiatische Studien — Études Asiatiques, 71/3 (2017) 